\title{
Onze: a rizomática narrativa de Bernardo Carvalho
}

\section{RESUMO}

Luciane Bernardi de Souza

lucibernardi@gamil.com

Universidade Federal de Santa Maria Santa Maria, Rio Grande do Sul

Vera Lúcia Lenz Vianna lenzvl@gmail.com Universidade Federal de Santa Maria Santa Maria, Rio Grande do Sul

\begin{abstract}
O presente artigo tem como objetivo estabelecer o diálogo entre o romance "Onze" (2011) do autor Bernardo Carvalho e a Teoria do Rizoma, dos teóricos Gilles Deleuze e Félix Guattari, esta última pensada a partir de uma leitura social. Interpretando este romance e compreendendo a sua estrutura discursiva, propomos uma analogia entre essa obra literária e as estruturas sociais externas apontadas pela teoria deleuze-guatariana, de modo a compreender "Onze" como uma narrativa-rizomática.
\end{abstract}

PALAVRAS-CHAVE: Rizoma. Narrativa contemporânea. Onze. 


\section{Introdução}

Primeiro romance do escritor Bernardo Carvalho, Onze: uma história (1995), publicado pela editora Companhia das Letras, apresenta a imagem de um mundo interconectado, rizomático. A aguçada sensibilidade do escritor em perceber e sentir a realidade contemporânea e engendrar através do discurso uma obra que represente o atual momento histórico surpreende principalmente pela construção que apresenta, uma vez que encontramos narrativas contadas a partir de distintos olhares, com personagens que se conectam repentinamente em diferentes capítulos da obra e vidas entrelaçadas pela força do acaso, evidenciando assim rupturas com as formas narrativas tradicionais do gênero romance.

Semelhante à construção de narrativas cinematográficas contemporâneas como Short Cuts - cenas da vida (1993) de Robert Altman Pulp Fiction (1994), do diretor Quentin Tarantino, Magnólia (1999) de Paul Thomas Anderson, 11:14 (2003) de Greg Marcks, Eu, você e todos nós (2005) de Miranda July, Babel (2006), 21 Gramas (2003), Amores Perros (2000) dirigidos pelo cineasta Alejandro González Iñárritu, 360 (2011) do diretor brasileiro Fernando Meireles e Para Roma, com Amor (2012) de Woody Allen, Onze é constituída por três segmentos ( $O$ sítio, Os gritos do Rio de Janeiro e $A$ causa) que aparentemente não apresentam nenhuma relação imediata entre si. No entanto, uma leitura mais atenta da obra revela determinados entrelaçamentos entre personagens e temas dos segmentos constitutivos, com encontros e desencontros aparentemente movidos pela força do imprevisto.

O fato das três partes da obra poder ser compreendidas separadamente, sem interferência alguma no entendimento da totalidade de Onze, também é uma problemática que deve ser investigada, pois nos leva ao questionamento de qual gênero o livro pertence, que ora parece aproximar-se da estrutura do gênero conto, ora adquire tonalidades do gênero romance, quando vista em sua totalidade. No entanto não nos deteremos nessa questão, pois o intuito do presente estudo é buscar compreender, a partir da imagem-metáfora do rizoma elaborada pelos teóricos contemporâneos Gilles Deleuze e Félix Guattari, e cujo conceito acreditamos que consegue analogicamente definir a construção e constituição da obra, qual a imago mundi que Onze comunica e como é construída.

\section{O real: fonte de energia das ramificações}

Onze exige do leitor e do crítico um deslocar-se para "fora" da obra, pois ao configurar-se como livro-máquina (denominação de Deleuze e Guattari para a manifestação estético-literária que rompe com o modelo de literatura canônica) expele questionamentos sobre a vida, o homem e o mundo que são representados não somente através das temáticas presentes na obra, mas principalmente em função do modo como é construída discursivamente. Diante desse romance de Bernardo Carvalho nos embasamos nas noções de Deleuze e Guattari (1995) e afirmarmos que, frente a literatura contemporânea, não cabe a pergunta "o que um livro quer dizer, significado ou significante?" (1995, p.2), mas sim "com o que ele funciona, em conexão com o que ele faz ou não passar intensidades, em que multiplicidades ele se introduz e metamorfoseia a sua, com que corpos sem órgãos ele faz convergir o seu" pois "um livro existe apenas pelo fora e no fora" (DELEUZE e GUATTARI, 1995, p.2). 
Nesse sentido, a tentativa de compreensão de qual imago mundi esta obra está produzindo através da sua construção e de seu diálogo com o real nos remete ao escorregadio território conceitual da representação literária. Ao optarmos pela defesa do elo umbilical que a obra literária estabelece com a realidade, alimentando-se desta ao mesmo tempo em que esta última também acaba por nutrir-se e enriquecer-se do fazer estético, entendemos o fazer literário como representação e recriação, e não mera cópia ou reflexo de uma dada realidade. Assim, abandonamos a lógica binária simplista da imago mundi que Deleuze e Guattari referem como "insípida" ${ }^{1}$, considerando o múltiplo da realidade, que só é possível em função do retorno que a máquina-livro apresenta ao real. Ratificando este direcionamento, em Literatura e sociedade (2006), o crítico brasileiro Antônio Candido enfatiza a necessidade de compreensão dos fatores externos que incidem sobre a criação literária, ponderando que o entendimento da obra, como elemento íntegro, só ocorre se fundirmos

\footnotetext{
texto e contexto numa interpretação dialeticamente íntegra, em que tanto o velho ponto de vista que explicava pelos fatores externos, quanto o outro, norteado pela convicção de que a estrutura é virtualmente independente, se combinam como momentos necessários do processo interpretativo. Sabemos, ainda, que o externo (no caso, o social) importa, não como causa, nem como significado, mas como elemento que desempenha certo papel na constituição da estrutura, tornando-se, portanto, interno (2006, p.13).
}

No entanto, tal posicionamento pressupõe definirmos qual o referente que estamos considerando, ou seja, aquilo que estamos tomando por real/realidade. Obviamente não nos aprofundaremos nesta ontológica questão, no entanto não podemos ignorá-la, pois afinal, o real é a superfície, o solo do qual o rizoma não somente se alimenta, mas também distende a multiplicidade e heterogeneidade de seus ramos.

\section{O "real" do sistema rizoma}

Desde as origens da filosofia ocidental o homem preocupa-se em criar conceitos e ferramentas teóricas que busquem auxiliá-lo na compreensão do mundo, que busquem racionalizar o real e assim tornar possível seu entendimento. Essa incessante procura humana, que possui o intuito de ordenar, compreender e representar a totalidade do real através da linguagem resultou, ao longo de toda a história do conhecimento, na criação, no estabelecimento e na consolidação de um arquétipo epistemológico: o paradigma arbóreo, que inerte, impede o diálogo e o encontro entre as ramificações (ciências/disciplinas), refutando aquilo que não apresente uma estrutura sólida e estável de saber e poder. Em acordo com Deleuze e Guattari, estes observaram "como a árvore dominou a realidade ocidental e todo o pensamento ocidental, da botânica à biologia, a anatomia, mas também a gnoseologia, a teologia, a ontologia, toda a filosofia" (DELEUZE e GUATTARI, 1995, p.11).

Essa "cultura arborescente", hierárquica, rígida, ancorada nos princípios da linearidade (início, meio e fim) e sequencialidade (causa e efeito) sempre impuseram a lógica da ordem e da hierarquia como o verdadeiro horizonte definidor do real, horizonte este que influenciou não somente o modo como o homem organiza o mundo (em grupos sociais hierarquizados, por exemplo), mas também a sensibilidade e desejos humanos. Ainda que hoje alguns discursos 
(científicos, filosófico-epistemológicos e estéticos) considerem a predominância de certa tendência à entropia, à probabilidade e ao caos, a necessidade de estabilidade preponderou tiranicamente até finais do século XIX, estabelecendo a ordem como a chave da existência de tudo o que nos circunda e impossibilitando o surgimento de qualquer pensamento que se "desviasse da norma".

O conceito de realidade alicerçado na lógica determinista é facilmente explicado se direcionamos nosso olhar para o passado e observarmos que durante toda a trajetória da episteme as noções de lógica, certeza e hierarquia foram predominantes. Nessa perspectiva, de acordo com o teórico Victor Bravo em sua obra Terrores de Fin de Milenio: del orden de la utopía a las representaciones del Caos (1999) foi com Pitágoras e Platão que iniciou-se a exclusão total do princípio de incerteza do real, prevalecendo assim o princípio absoluto da ordem e da figura de Deus como agente ordenador do mundo; na sequência, segundo o autor, os pré-modernos continuaram resistentes aos fundamentos de desestabilização, resistentes ao caos e ao acaso, sendo somente na modernidade que se começou refutar o centralismo cósmico e divino e substituí-lo pela razão. A sociedade racionalista moderna ao criar uma nova inteligibilidade de ordem enalteceu a ciência e a lógica, mas seguiu excluindo os elementos desestabilizadores da ordem, pois assegurava suas bases na exatidão e na perfeição, uma vez que, segundo Einstein, "Deus não joga dados".

A reviravolta veio somente com as correntes de pensamento do fim do século XIX. Foi com Nietzsche e Schopenhauer que a "essência" do real foi posta em xeque, e o questionamento em torno do real único e homogêneo estabelecido inaugurou a reflexão sobre a verdadeira construção deste. Nesse sentido, fez-se necessário começar a interrogar os signos, sistemas e paradigmas que construíram (e constroem) o conhecimento e, para tal, instaurou-se a autorreferencialidade e a recursividade das linguagens, momento em que as disciplinas começaram a questionar-se, abandonar seus postos fixos no sistema arborescente e voltaremse para si, questionando suas bases e propondo novos meios de pensar e construir o conhecimento que, por sua vez, estabelece determinadas imagens da realidade.

Com o intuito de ampliar as possibilidades de construção do pensamento, de problematizar e minar as correntes hierárquicas sustentadoras do pensamento ocidental, novos discursos teóricos e científicos encetaram a dúvida em torno do próprio discurso, que não somente construía, mas assegurava uma imagem da realidade. Visualizando nessa a presença do acaso, do incerto e da dúvida, a Geometria Euclidiana foi em 1974 desestabilizada pela Geometria Fractal; na sequência os princípios da Mecânica Clássica newtoniana foram questionados pela teoria da Mecânica Quântica que se fundamentava nos pressupostos de possibilidade e instabilidade; no campo da Física e da Matemática a Teoria da Catástrofe (1972) veio acompanhada da Teoria do Caos, que influenciaram o campo da epistemologia e do conhecimento para a criação de um pensamento mais complexo em relação à realidade, abrindo espaço para a Teoria da Complexidade de Edgar Morin, o Desconstrutivismo de Jaques Derrida e o Sistema Rizoma de Gilles Deleuze e Félix Guattari, entre muitas correntes que "estremeceram" o sistema arbóreo e desestabilizaram sua base, até então estável. Sobre a força atributiva da ciência determinista, Edgar Morin em sua obra Introducción al Pensamiento Complexo (1990), adverte que 
a los métodos de verificación empírica y lógica. Mitos y tinieblas parecen ser rechazados a los bajos fondos del espíritu por las luces de la Razón. Y, sin embargo, el error, la ignorancia, la ceguera, progresan, por todas partes (1990, p.27).

Direcionando sua crítica ao sistema arbóreo do conhecimento, sustentado pela noção escorregadia da razão, o autor aponta que as causas de tais indícios são resultados dos modos de organização de nosso saber em sistema de ideias, "un modo mutilante de organización del conocimento, incapaz de reconocer y de aprehender la complejidad de lo real" (1990, p.28), na medida em que estamos cercados de paradigmas de simplificação que "mutilan el conocimento y desfiguran lo real" (MORIN, 1990, p.29), desconsiderando a multiplicidade e o entrelaçamento contínuo de sistemas e fenômenos que compõem o mundo.

Esta visão defendida pela Teoria da Complexidade também pode ser encontrada nos novos discursos científicos e epistemológicos do fim do século XX e começo do século XXI, que começaram a apontar para um novo modo de pensar realidades até então ignoradas, realidades nas quais a força da probabilidade, da incerteza, do acaso e da conexão são elementos formadores. Tais questionamentos resultaram na desestabilização do modelo arbóreo, ordenado e fundamentado na certeza, no qual o fluxo de informações apenas poderia percorrer os rígidos caminhos internos já estabelecidos pela árvore do conhecimento.

Subvertendo a lógica arbórea e na contramão de conceitos e representações que sempre impuseram uma leitura logocêntrica e determinista do real, o conceito-imagem do Rizoma, do filósofo Gilles Deleuze e do psicanalista Félix Guattari, presente nas páginas do livro Mil platôs - capitalismo e esquizofrenia (1995) lança outro olhar sobre o real. Acreditando que o pensamento não é arborescente, Deleuze e Guattari buscam abranger o múltiplo na/da contemporaneidade através do rizoma, que sem limites definidos, sem entradas e saídas exatas, percorre livremente o espaço e consegue representar um novo modo de conceber o conhecimento, conhecimento esse que engendra um novo real. Sobre esse novo modo de conceber a realidade, os teóricos afirmam:

Ser rizomorfo é produzir hastes e filamentos que parecem raízes, ou, melhor
ainda, que se conectam com elas penetrando no tronco, podendo fazê-las
servir a novos e estranhos usos. Estamos cansados da árvore. Não devemos
mais acreditar em árvores, em raízes ou radículas, já sofremos muito. Toda a
cultura arborescente é fundada sobre elas, da biologia à linguística. Ao
contrário, nada é belo, nada é amoroso, nada é político a não ser que sejam
arbustos subterrâneos e as raízes aéreas, o adventício e o rizoma (1995, p.10).

Segundo os teóricos mentores da "máquina anárquica" que é o sistema rizoma, este apresenta alguns elementos principais que o definem. $O$ primeiro deles é a força da conexão entre diversos pontos, no qual "qualquer ponto de um rizoma pode ser conectado a qualquer outro e deve sê-lo" (DELEUZE e GUATTARI, 1995, p.04), assim como a ausência de uma unidade superior e de um sistema hierárquico centrado e fundamentado em uma raiz central, no qual não há mais lugar para o caule, definidor e hierárquico, centralizador de toda a energia do sistema. A heterogeneidade, segundo princípio, estabelece que as hastes espalhadas formam fluxos subterrâneos, formando realidades heterogêneas através de "decomposições estruturais" e "descentramentos" que, por sua vez, expõem multiplicidades "que mudam necessariamente de natureza à medida que 
aumenta suas conexões. Não existem pontos ou posições num rizoma como se encontra numa estrutura, numa árvore, numa raiz. Existem somente linhas." (DELEUZE e GUATTARI, 1995, p.05). O princípio de ruptura a-significante defende que o sistema rizoma pode ser rompido e segmentado em qualquer ponto, mas que, no entanto, sempre retomará inteiro, alongando-se "segundo uma ou outra de suas linhas e segundo outras linhas. Há ruptura no rizoma cada vez que linhas segmentares explodem numa linha de fuga, mas a linha de fuga faz parte do rizoma. Estas linhas não param de se remeter umas às outras, fazendo contatos com o externo, invadindo e conjugando fluxos, sem apresentar um início e um fim, mas um meio pelo qual ele cresce, transborda e invade. $O$ quinto e sexto elementos definidores referem ao poder de cartografia e a negação da calcomania: "um rizoma não pode ser justificado por nenhum modelo estrutural ou gerativo. Ele é estranho a qualquer ideia de eixo genético ou de estrutura profunda" (DELEUZE e GUATTARI, 1995, p. 08), ele é superficial em sua natureza, sendo um mapa, e não um decalque ou reprodução. Ele movimenta-se e expandese rapidamente, é desmontável, passível de ser construído, aberto, conectável em todas as suas dimensões, não podendo ser copiado, pois sua forma é reversível e passível a constantes transformações.

Nesse sentido, a árvore resistente e indestrutível do conhecimento é dilacerada pelas tempestuosas forças do pensamento contemporâneo, que com rajadas de ventos avassaladoras parece estar varrendo-a do cenário do conhecimento e cedendo lugar ao rizoma subterrâneo, mais adaptável, flexível, resistente a ventos fortes por justamente vivenciar o underground. No entanto, apesar desses avanços tanto no campo da ciência quanto da filosofia, Victor Bravo (1999) alerta que sempre estamos perigosamente presos aos limites da linguagem. No entanto, para o autor, a arte e a literatura escapam totalmente ao peso da lógica e da ordem, fundando um lugar de resistência, sendo lugares privilegiados para o surgimento de figuras "desordenadas", que criticam os fundamentos absolutos. Ambas são ferramentas de construção de novos reais, que ajudam a legitimar e deslegitimar o conceito homogêneo de realidade, gerando espaço não somente para uma crítica ao real, mas de criação de reais até então escamoteados, inomináveis. Nesse sentido, não é somente a ciência e a filosofia que realizam o questionamento das estruturas e dos processos de legitimação do mundo, mas a arte e a literatura também auxiliam na desconstrução de todo um sistema de pensamento homogêneo, evidenciando as descontinuidades, as rupturas e as lógicas ilógicas e originando assim novos reais.

Considerando a força do discurso estético, visualizando o perfil deste conceito instrumental denominado rizoma e buscando analogicamente visualizá-lo na construção de Onze, conseguimos detectar que ao engendrar um romance que apresenta multitemporalidades e multiespacialidades, com personagens que parecem mover-se impulsionados pela força do aleatório, do acaso e da incerteza, Bernardo Carvalho põe em questão justamente a estabilidade e as certezas do real homogêneo e controlável. Desse modo, refletindo justamente sobre este possível diálogo entre pressupostos científicos e a arte contemporânea, o filósofo, semiólogo e linguista contemporâneo Umberto Eco afirma que 
saber, produtivamente empenhado num progresso de suas faculdades e de seus horizontes. (ECO, 1971, p.59)

Para compreendermos melhor qual o diálogo que a imago mundi de Onze apresenta não somente com o conceito de rizoma, mas com esses novos âmbitos do pensamento científico e filosófico contemporâneo, adentramos nas suas emaranhadas tramas, percorrendo seu sistema rizomático e buscando evidenciar como é alicerçada esta imagem-metáfora constituída pelo perambular dos personagens e temas que se "alastram" na totalidade da obra, formando diversas linhas narrativas e raízes de um sistema interconectado, emaranhado, rizomático.

\section{Sobre cruzamentos e aberturas}

Sem uma estrutura rígida e pivô central hierarquizador, Onze é segmentada em três grandes partes interconectadas: a primeira delas, $O$ sítio, construída a partir de um olhar onisciente que realiza malabarismos narrativos através de longos parágrafos interruptos e discursos indiretos, apresenta o fim de semana de um grupo de onze amigos e familiares em um sítio no interior do Rio de Janeiro e que nessa ocasião, vivenciam conflitos pessoais: segredos são revelados, e angústias evidenciadas entre Alice, Trudi, Gui, Rodolfo, Gregório, Lilian, Dulce, Antonio, Nina, Rubens e Álvaro. Também são mencionados os nomes de Adriana, Mário, o artista holandês, e Marta, personagens secundários que aparecerão nas outras partes da obra.

A segunda parte intitulada Os gritos do Rio de Janeiro, divide-se em dois capítulos denominados oaeooeoe e $O$ país do dinheiro. $O$ primeiro dos relatos, oaeooeoe, é narrado por um ex-aluno do pintor holandês Kill, Bernardo, cuja dificuldade era ler artigos definidos. O narrador relata sua inserção na oficina juntamente com outros dez meninos e suas impressões negativas sobre o artista, além da ideia obsessiva de matá-lo. Já no segundo capítulo, $O$ país do dinheiro, o narrador é um crítico de arte e especialista no trabalho de Kill, que presenciara a cena da aposta deste com um estudante brasileiro de doutorado em História da arte.

A terceira parte, $A$ causa, é formada por seis capítulos: $A$ fotógrafa, Um dos herdeiros, Os órfãos, Os idênticos, $O$ contrato e $O$ aeroporto. Os cinco primeiros apresentam os últimos momentos de vida de onze destinos que serão interrompidos em um atentado terrorista no aeroporto de Orly-Paris, mencionado na primeira parte do livro, acidente que ocorreu em função da perseguição a um herdeiro de uma grande fortuna e membros da seita da qual fazia parte, e que desejavam matá-lo. O sexto capítulo, $O$ aeroporto, apresenta o massacre dos onze personagens presentes nesta terceira parte no hall do aeroporto de Orly, em Paris.

\section{Personagens desterritorializados}

Em $O$ sítio, primeiro segmento, estão presentes alguns personagens principais (que fazem parte dos onze visitantes do sítio) e secundários (apenas mencionados por alguns dos onze) que reaparecem nas outras partes da obra, direta ou indiretamente. São eles: Trudi, advogada e filha de Alice; Adriana, atriz de teatro e mulher de Mário; o apostador, ex-marido de Nina e o pintor holandês, que na primeira parte ainda não possui seu nome revelado, mas que é mencionado por 
Trudi e Rubens e reaparece como figura de destaque no primeiro e segundo capítulos da segunda parte. Vejamos o trecho narrado em que dialogam Nina e Álvaro, e no qual são mencionados Adriana e o pintor holandês, personagens que reaparecem no segundo segmento da obra:

Com os braços em cima da boia, Álvaro perguntou a Nina se nunca mais tinha encontrado Adriana $^{2}$ e ela primeiro se surpreendeu com a pergunta- não sabia que a conhecia-, depois achou que ele devia ser apenas mais um fã da ex-amiga e disse que com o caso do pintor holandês, que todos os jornais noticiaram, ele devia saber, ficou mais difícil, quase impossível, para as duas voltarem a ser amigas, porque o destino as colocou em campos opostos (...) (CARVALHO, 1995, p.22)

Embora na primeira parte ainda não seja possível que saibamos quem foi o pintor holandês e a aposta/caso/processo que foi realizada entre ele e o ex-marido de Nina, este é novamente mencionado em um diálogo entre Rubens e Trudi, em que Rubens condena Trudi e a chama de "velha assustada e ranzinza" que acredita ser como ela "vinha se sentindo desde que perdeu o caso do pintor holandês, desde que todo o Rio de Janeiro comentou o desfecho daquele processo, e ela o tomou como se fosse fracasso seu" (CARVALHO,1995, p. 24) . O pintor holandês, assim como o tal "processo/caso" novamente irrompem na primeira parte da obra, agora mencionados por Álvaro, (visitante do sítio e primeiro "namorado" de Adriana) que medita a respeito de Nina e acaba por aludir ao seu (ex)marido, ao processo e ao pintor holandês

(...) Nina e o marido estavam na Inglaterra (ela o acompanhou quando ganhou a bolsa de doutorado em história da arte e se separaram logo ao voltarem) nunca o tinha visto e ficou com a imagem de um sujeito estranho, calado, sobretudo depois de ouvir sobre o processo e a história do pintor holandês, que para ele nunca ficou clara (...) (CARVALHO, 1995, p.40).

De maneira indireta, ainda no primeiro segmento são realizadas menções ao personagem denominado de Jorge, (o clochard de Paris presente no terceiro segmento da obra, no capítulo Os idênticos,) que é referido na discussão de Gui e Lilian:

(...) o que mais temia, que fosse hereditário, coisa de família, como a tia que chegou a tocar fogo nas cortinas do apartamento e agora vivia sob remédios, tinha enlouquecido aos poucos, desde que o filho desaparecera, seu primo, (...) Jorge o nome do primo que desapareceu durante a repressão e um belo dia foi visto vagando pelas ruas em Paris, vestido como um mendigo (CARVALHO, 1995, p.30).

Ainda no primeiro segmento da obra, encontramos menção à filha de Marta, Carminha, com seu filho Pedro, que reaparecem no primeiro capítulo do segundo segmento de Onze. No trecho a seguir podemos encontrar estes três personagens sendo mencionados pelo narrador:

Marta tinha prevenido as filhas, mas mesmo assim a Carminha foi tonta, ela pensou, agora tinha que morar longe com a criança, que Marta nunca tinha visto até a filha mandar a foto, sem que o Manuel, o caseiro, pudesse saber, senão matava as duas, e Marta pegou o ônibus e viajou cinco horas só pra ver de novo a filha na Baixada e o menino, Pedro, que ela pegou nos braços e chorou (...) (CARVALHO,1995, p.46). 
A partir desse breve mapeamento de personagens encontrados no primeiro segmento de Onze, é possível visualizarmos algumas ramificações importantes na constituição dessa obra que, como veremos na sequência, alastram-se, pondo em evidencia a vinculação de diversas dimensões de Onze. Vejamos: se a figura do pintor holandês, assim como a questão do processo são apenas mencionadas superficialmente nessa primeira parte, não acarretando nenhum empecilho para o entendimento da obra, esse mesmo pintor é o personagem central dos dois capítulos que conformam a segunda parte da obra. Com isso, a imagem que se conforma é a de que esse personagem, ramificação enfraquecida nesta primeira parte, toma vigor, rompe a barreira entre uma narrativa e outra e desloca-se até a segunda, se alocando ali de modo a garantir sua predominância. Além desse personagem, em $O$ sítio também aparece Jorge, que também apenas mencionado pela personagem Lilian nessa primeira parte, no capítulo Os idênticos (terceira parte) é o personagem principal, sendo apresentada sua trajetória de vida e destino. Além do pintor holandês e do personagem Jorge, também são mencionadas figuras secundárias como Carminha e seu filho Pedro, que assim como o pintor holandês e Jorge, ao ramificarem-se e invadirem "territórios alheios" (capítulos) ganham força e destaque na totalidade da obra.

Em oaeooeoe, primeiro capítulo da segunda parte de Onze (Os gritos do Rio de Janeiro) narrado por Bernardo, um dos meninos que participa da oficina do artista holandês reaparece, assim como a figura de Maria do Carmo, a Carminha, e de Pedro, filho desta e também pertencente ao grupo de meninos adotados pelo artista holandês em sua oficina, e que neste capítulo é encontrado morto, sem os órgãos, na Baixada fluminense:

Ela conseguiu emitir o primeiro som, o nome do filho, Pedro, ela disse (...). Minha mãe ouviu da boca de uma mulher que acompanhou Maria do Carmo até o mangue onde acharam o corpo embrulhado em jornais. (...) desde que tinha engravidado daquele menino, tinha perdido toda a família, não tinha mais ninguém, foi esquecida pelos pais, que a obrigaram a ir embora e acabar ali, naquele buraco, sozinha com a criança (...) (CARVALHO,1995, p.76)

O trecho acima indica que a personagem Maria do Carmo ao estar grávida de Pedro foi abandonada pela família. Tal situação corresponde exatamente a mesma situação vivida pela personagem Carminha, mencionada na primeira parte da obra: "Carminha foi tonta, ela pensou, agora tinha que morar longe com a criança (...) o menino, Pedro, que ela pegou nos braços e chorou (...)" (CARVALHO, 1995, p.46). Em ambas as partes da obra, tanto a situação como o nome do filho, Pedro, nos leva a afirmar que se trata dos mesmos personagens-ramos, que brotam em diferentes segmentos de Onze.

Ainda neste primeiro capítulo (do segundo segmento) destacamos o fato de o narrador personagem Bernardo, integrante do grupo de onze meninos que fazem parte da oficina do pintor, alimentar por este último um ódio dilacerado, como podemos conferir no trecho a seguir, em que Bernardo idealiza o assassinato de Kill, o pintor holandês: tiros, porque errarei o primeiro, que vai entrar na barriga, o segundo no peito e por fim na cabeça, que nem sei mais se é por bem ou por mal. Posso errar o primeiro, mas não vou me enganar. Não vou nem olhar para cima, para as nuvens passando, que são iguais em qualquer lugar e para qualquer um, por 
que a essa altura já vou ter percebido que deixei de acreditar. Depois, ao lado do buraco da segunda bala, no peito, vou escrever oaeooeoe, e vou ler em voz alta. (CARVALHO,1995, p.79)

Em O país do dinheiro, segundo capítulo (presente na segunda parte), encontramos personagens-ramos já encontrados anteriormente, e que cruzam por novas narrativas completamente distintas das anteriores. A primeira é a personagem Trudi, advogada de defesa do marido de Nina no processo movido pelo marido contra o pintor, referida de modo indireto pelo narrador

Pelo artigo, que trata do delírio daquela aposta, depreende-se que, no dia 11 de maio, cinco meses depois da palestra portanto, um rapaz bem apessoado adentrou uma vila de Notting Hill, em Londres, procurando a casa de número 5 - a versão é da advogada de acusação, por assim a brasileira que descreveu a cena á corte (CARVALHO, 1995, p.81).

O apostador, ex-marido de Nina, referido novamente pode ser localizado no seguinte trecho: “(...) hoje, no jornal, lembrei perfeitamente daquela palestra do pintor, quando de repente, no meio da plateia, um rapaz se levantou e disse que conhecia um lugar onde o trabalho dele não daria certo, em lembro que disse "o verdadeiro país do dinheiro..." (CARVALHO, 1995, p.80). Esse rapaz referido no trecho é o ex-marido de Nina, fato que pode ser comprovado pela profissão deste na primeira parte da obra: “(...) Nina e o marido estavam na Inglaterra (ela o acompanhou quando ele ganhou a bolsa para o doutorado em história da arte", em relação a apresentada neste segundo capítulo da segunda parte: "(...) em Londres, Kill e o rapaz, que estava terminando seu doutorando em história da arte" (CARVALHO, 1995, p.83) em que ambas mencionam a profissão deste personagem, ex-marido de Nina que realiza a aposta com o pintor holandês, e cujo nome não conhecemos.

Adriana e Mário, presentes na primeira parte da obra, são outra vez mencionados: "Numa dessas festas conheceu uma atriz, que o artigo classifica sarcasticamente como "shakespeariana"(...) ela reencontrou o marido, um diretor de teatro (o artigo diz que é reputado pela forma como faz seus atores gritarem)" (CARVALHO, 1995, p.90). Podemos inferir que aqui encontramos Adriana e Mário em função das profissões de ambos, já explicitadas na primeira parte da obra em trechos como: "Adriana tinha se tornado uma verdadeira atriz" e "os problemas dos atores de Mário é que eles gritam muito" (CARVALHO,1995, p.22), que se aproximam das características apresentadas nesta segunda parte.

O personagem narrador do primeiro capítulo da segunda parte (oaeooeoe), Bernardo, é aludido de modo indireto nesSe segundo capítulo. Sabemos que se trata de Bernardo, o assassino, pois no primeiro capítulo encontramos exatamente o planejamento que Bernardo havia feito sobre o assassinato do pintor Kill, que é concretizado no capítulo dois, e descrito:

Foi ao sair de um desses jantares que acabavam sempre se transformando em festas, de madrugada, sozinho, com a intenção de seguir pela avenida Brasil, segundo o artigo, até a Baixada, que Kill desapareceu e foi encontrado dois dias depois, com um tiro na cabeça, um no peito e outro na barriga e, ao lado do buraco da bala no peito, uma inscrição indecifrável, que a polícia e os investigadores simplesmente abandonaram depois de inúmeras tentativas e hipóteses: oaeooeoe. $\mathrm{O}$ assassino (a polícia não descarta a hipótese se ser uma quadrilha) não foi encontrado (CARVALHO,1995, p.91) 
Através dos trechos mencionados anteriormente, visualizamos que personagens-ramos da primeira parte da obra como Nina e seu ex-marido, Trudi, Adriana, Mário, Pedro e Carminha, assim como o próprio pintor holandês, irrompem, crescem, estendem-se e são novamente encontrados nos capítulos do segundo segmento, alguns até mesmo desempenhando um papel mais relevante em relação ao que ocupavam na primeira, como é o caso do pintor holandês, de Pedro, do ex-marido de Nina e de Trudi.

Na terceira parte, A causa, encontramos mais alguns personagens-ramos presentes em partes anteriores, mas inseridos agora em um enredo totalmente diverso. Em A fotógrafa, primeiro capítulo do terceiro segmento, reaparece o artista holandês Kill, na ocasião em que a fotógrafa Verônica vai ao apartamento deste em Nova York para entrevistá-lo: "Quase esqueceu o encontro que tinha marcado para aquela mesma tarde, no apartamento do artista (...) Era um velho projeto sobre celebridades que tinham morado no Brasil. (...)/ Comecei a trabalhar com crianças da periferia, crianças com problemas de aprendizado. Foi assim que dei início à oficina" (CARVALHO, 1995, p.101). Tal trecho, além de apresentar o artista, também explicita seu projeto desenvolvido no Brasil com os meninos da Baixada fluminense, na oficina, que é desenvolvido no primeiro capítulo da segunda parte.

Em A fotógrafa é narrada a perseguição da fotógrafa em busca do jornalista brasileiro, e que em meio à persecução o vê dando carona a duas crianças até Paris, que é pra onde está rumando na tentativa de ver um amigo que está morrendo: "Confirmou na estrada, não na auto-estrada, mas quando ele tomou um caminho secundário, estreito e tortuoso, e só parou uma vez, para pegar uma menina e um menino que pediam carona, à saída de Trier, até entrar na França" (CARVALHO,1995, p.110). Por sua vez no capítulo seguinte, Os Orfãos, essas duas crianças são os personagens principais e recebem o nome de Gui e Cristina, capítulo no qual esse jornalista é encontrado outra vez, pois a descrição da situação e contexto em ambos os capítulos (Os Orfãos e A fotógrafa) é a mesma, como podemos conferir no trecho a seguir:

\footnotetext{
Mal pisou no acostamento e já estava com o braço estendido para um carro azul que entrava na curva. Era o primeiro carro. Cristina viu que, ao passar por eles, o motorista a olhou. Ela olhou para ele também e viu seu rosto. 0 carro parou uns cinquenta metros mais à frente e os dois correram até lá."/ “Para onde vocês vão?", perguntou o motorista, em inglês./ Cristina olhou para o irmão, que vinha logo atrás dela e ainda corria, e virou-se para o motorista: "Para onde você está indo?"/ "Paris"./ "Paris está bem (CARVALHO,1995, p.130).
}

Em Os idênticos, quarto capítulo da terceira parte, reaparece Jorge, primo de Lilian, já presente em $O$ sítio, primeira parte do livro. O capítulo apresenta a história de um funcionário da embaixada brasileira que possui um amigo de infância (um clochard brasileiro) perdido em Paris, amigo este que já foi diversas vezes avistado por turistas brasileiros e até mesmo por ele, mas que misteriosamente não consegue ser encontrado pelo funcionário. A história deste clochard é então apresentada: militante de esquerda no Brasil na época do regime militar, esse foi para a Europa passar uma temporada em Paris conheceu um 
amigo/companheiro, e ao voltar para o Brasil trouxe consigo seu companheiro. Ambos se envolveram ainda mais na luta contra a repressão, e quando alguns companheiros começaram a cair, eles tiveram que engendrar um plano: enquanto seu companheiro ficou no Brasil, ele, o clochard, foi para Paris com o passaporte do amigo, já que eram fisicamente semelhantes. No entanto seu amigo, que ficou no Brasil, acabou caindo: ao tentar sair do país (com um novo passaporte, pois alegou que havia perdido o outro), foi detido no aeroporto, torturado e morto. $\mathrm{O}$ corpo foi entregue a mãe do clochard como se fosse o corpo do seu filho. A mãe, inconformada com a morte daquele que ela acreditou ser o filho, manteve um cartaz pregado na janela do escritório onde trabalhava escrito "onde está o Jorge? " (CARVALHO, 1995, p.140), trecho este que revela o nome do personagem, e que nos leva (juntamente com as características relativas à sua vida) ver que se trata do mesmo personagem.

Este entrecruzamento de personagens entre as partes de Onze também é visualizada no último capítulo da última parte, $O$ aeroporto, no qual ocorre a reunião, aparentemente ao acaso, de todos os personagens presentes nos capítulos da terceira parte da obra (o herdeiro, o crítico da arte de Kill mais dois homens, o funcionário da embaixada seu amigo cloachard, os órfãos, a fotógrafa, o jornalista e a aidética) personagens estes que, como vimos, em sua maioria possuem ligações com os personagens e histórias das outras duas partes da obra, ainda que cada narrativa pareça manter sua relativa autonomia.

O trecho a seguir, apresenta o massacre desses personagens, agora lado a lado em um único tempo e lugar, no aeroporto de Orly, em Paris:

\begin{abstract}
Foi um massacre. Os jornais trouxeram a lista dos mortos. Os guardas cercaram o aeroporto e os corpos caídos ali, todos no chão, esperando identificação: o herdeiro ninguém nunca vai saber por quê; a fotógrafa porque queria ver; a aidética como um passarinho, por causa do coração; os órfãos porque estavam na frente das balas, correram ao invés de se jogarem no chão, com os outros, onde acabaram de qualquer jeito; um grupo de três críticos de arte, por uma triste coincidência; o mendigo na confusão, assim como o funcionário, tentando salvá-lo; e o jornalista, por engano. (CARVALHO, 1995, p.145)
\end{abstract}

Neste último trecho visualizamos a supressão da ordem causal que preside a vida. O terrorismo, e o abrupto de realidade interligada, que se movimenta e se expande rapidamente, é desmontável, passível de ser construída, aberta, conectável em todas as suas dimensões, A heterogeneidade, em que hastes se espalham e há fluxos formando realidades heterogêneas expõe a multiplicidade rizomática, que com linhas abstratas e pontos de fuga, busca a máxima desterritorialização.

A maior parte dos personagens-ramos mencionados nos três segmentos obra não se mantém fixos apenas em um deles, mas, ensimesmados, errantes e desenraizados buscam algo e nessa busca deslocam-se, transitam, estendem-se. Tal configuração, que corresponde ao princípio rizomático da conexão, apresenta a interface dos personagens que, por sua vez, resulta em atrelamentos entre todas as partes da obra, em que, assim como no sistema rizoma, um ponto pode ligar-se ao outro inexistindo assim um esquema binário e hierárquico que impede o fluxo e o cruzamento. 


\section{Sobre outras ramificações}

Além dos personagens, podemos também encontrar a reiteração e expansão de outras raízes que irrompem e invadem simultaneamente os três segmentos da obra, são elas: o número onze, o vírus HIV e a notícia da tragédia no aeroporto de Paris. Além de dar título à obra, o número onze é visualizado na primeira parte dessa, quando são mencionados onze amigos e parentes que passam o fim de semana no sítio e que nessa ocasião vivenciam conflitos pessoais: segredos são revelados, e angústias evidenciadas entre Alice (mãe de Trudi, Nina e Rubens e dona da casa do sítio), Trudi (advogada) Gui (ex-namorado do tio Rodolfo), Rodolfo (irmão de Alice), Gregório (amigo de Rodolfo), Lilian (namorada de Gui), Dulce (filha de Alice), Antônio (companheiro de Dulce), Nina (ex-mulher do homem se envolveu em uma aposta com um pintor holandês), Rubens (quem convidou Álvaro para o fim de semana) e Álvaro (visitante do sítio e primeiro 'namorado' de Adriana).

Esse mesmo número é encontrado no segundo segmento da obra, quando onze meninos pobres da Baixada Fluminense, que possuem problemas de aprendizado, são acolhidos pelo artista plástico holandês. Por fim, o número onze é também encontrado na terceira parte da obra, quando onze pessoas são assassinadas no aeroporto de Paris- Orly: o herdeiro, o crítico da arte de Kill mais dois homens que decidiram ir ao Brasil para dar continuidade aos estudos críticos do pintor, o funcionário da embaixada, que ao trazer o embaixador que pegará o voo para o Brasil, no hall do aeroporto vê ao longe seu amigo cloachard, também assassinado. Os órfãos que correndo pelo hall tentavam descobrir onde seria o embarque para o Brasil, a fotógrafa Verônica Correa Fraga, que estava seguindo o jornalista que voltaria para o Brasil, e a aidética Sandra, que decidida ir para qualquer lugar distante, havia comprado uma passagem para o Brasil e, cansada, esperava o voo. Todos os onze morrem assassinados.

Além desse número, o vírus HIV é o outro elemento que percorre as partes e capítulos de Onze, simbolizando a desordem, aquilo que tende a destruição e a morte, mas que ao mesmo tempo revela o vigor e a força da interconexão em uma sociedade globalizada, que representa exatamente o entrelaçamento rizomático do sistema e que leva Deleuze e Guattari a afirmar que "Nós fazemos rizoma com nossos vírus" (CARVALHO, 1995, p.12).

Na primeira parte da obra acompanhamos a discussão entre o casal Dulce e Antônio sobre a contaminação desta pelo vírus HIV através de Antônio. Na terceira parte da obra este elemento reaparece novamente em três capítulos: em $A$ fotógrafa, no qual o narrador apresenta Verônica Correa Fraga, filha de fazendeiros paulistas ricos que foi morar em Nova York e lá conheceu Ronald Sand, que se tornou seu amigo e com o qual passeava todas as manhãs. Em um desses passeios Ronald comenta com Verônica que conheceu um jornalista brasileiro, e que teve relações sexuais (sem proteção) com ele. A fotógrafa fica estarrecida com a notícia, pois sabe que o amigo é soropositivo e a partir de então inicia uma perseguição ao jornalista, com ligações anônimas e registros fotográficos deste por todos os lugares. Esse mesmo elemento também aparece no capítulo denominado Os órfãos, no qual o narrado em terceira pessoa cede a voz para Cristina, menina que juntamente com seu irmão Guilherme, ao pegar carona de um desconhecido para Paris, conta a este a morte de seus pais, vitimados pelo HIV. Ainda na terceira parte da obra, no capítulo $O$ contrato, encontramos o HIV rondando a vida de 
Sandra, mulher aidética que acredita que possui apenas seis meses de vida e que em razão disso troca seu seguro de vida por uma quantia em dinheiro, usando-o todo para viajar para vários lugares do mundo.

Soma-se ao número onze e ao vírus contaminante do HIV a notícia da tragédia no aeroporto de Paris-Orly, que em $O$ sítio já é mencionada diversas vezes quando Lilian apresenta a misteriosa viagem de Dulce e Antônio, que saem do sítio com a desculpa de irem comprar jornais para saber algo mais sobre a tragédia do aeroporto de Paris:

Lilian tentando puxar algum assunto, falou do que deviam dizer os jornais, que Antônio e Dulce tinham ido buscar na cidade, sobre a história do aeroporto de Paris, que Gregório já tinha comentado longamente na véspera, com riqueza de detalhes, porque tinha ouvido no rádio do carro, enquanto passavam pela Baixada (...) a tragédia do aeroporto de Paris, o desaparecimento daquelas pessoas inocentes, continuava Lilian, tentando conter as lágrimas (CARVALHO,1995, p.20 e 21).

E quando Rubens se dirige a Trudi comentando sobre a preocupação desta em relação a demora de Dulce e Antônio: (...) não havia motivo para não estarem de volta, Dulce e Antônio, se tinham
ido apenas pelo jornal, e foi exatamente o que disse Rubens quando Trudi
abriu a porta da sauna e falou de sua preocupação, ele riu e disse que ela só
pensava no jornal, devia relaxar durante o fim de semana no sítio, afinal podia
ficar um dia sem ler o jornal, tentar esquecer o resto, as notícias, os horrores
da imprensa, as mortes, os extermínios, a tragédia no aeroporto de Paris,
"Você quer a lista de mortos, saber a história de cada um, e se conhecia algum
daqueles brasileiros que esperavam o voo, está precisando lamentar a morte
de alguém, quer descobrir a cauda de tudo, não é Trudi? (CARVALHO,1995, p.
24).

Somente compreendemos esta tragédia quando realizamos a leitura do último capítulo ( $O$ aeroporto) da terceira parte da obra, que narra esse acontecimento e o encontro de onze personagens que apareceram nos cinco capítulos anteriores desta terceira parte. Este capítulo intensifica a noção de mundo interrelacionado e a ideia de que um acontecimento distante é capaz de exercer influência em outros lugares e pessoas, revelando que estamos todos unidos de maneira mais ou menos consciente (como no caso do massacre, que fora largamente divulgado nos principais jornais e passou então a ser foco de atenção de diversas pessoas). $O$ aeroporto, como o lugar que sela o destino do indivíduo globalizado na sociedade contemporânea, pode ser tomado como o símbolo do estado plural em que se constrói a sociedade globalizada, que possibilita o cruzamento de histórias paralelas que se entrelaçam de algum modo. É o aeroporto o lugar da multidão que tece a trama da vida, lugar aparentemente destituído de identidade, de história, mas onde convergem desejos, vontades, onde pulsa a ânsia do encontro. É o lugar da alteridade, da diferença, da comunicação, do destino de muitos, contemporaneamente pode ser também visto como o destino final, a armadilha criada pela sociedade contemporânea.

Estes três elementos que percorrem a obra, visto como análogos ao sistema rizoma podem ser vistos como tubérculos hipertrofiados que irradiam energia para todo o sistema rizoma de Onze, através do processo de reiteração. Essas reiterações que apontam para o entrelaçamento entre os personagens, também apresentam como as decisões que tomamos podem afetar direta ou indiretamente 
a vida de outras pessoas, como no caso de Sand, que ao gerar em Verônica a preocupação em relação ao jornalista brasileiro, a faz segui-lo, resultando na morte desta justamente em decorrência desta perseguição; ou mesmo no caso dos órfãos, que sem a carona do jornalista brasileiro até Paris não teriam chego ao aeroporto, e consequentemente não seriam mortos; ou ainda caso do artista, que ao conhecer Adriana e ter com ela um filho, vem para o Brasil em busca deste último, mas acaba por desenvolver no Rio uma oficina para meninos pobres, meninos entre os quais estão Bernardo e Pedro, Bernardo seu futuro assassino e Pedro o neto de Marta, mulher do caseiro do sítio em que se passa a primeira narrativa; ou mesmo o herdeiro, que ao envolver-se em uma seita e ser perseguido e assassinado no aeroporto de Orly é responsável indireto também pela morte de outros dez personagens. A partir desta configuração é visualizada a imagem do rizoma, em que uma ramificação se entrelaça a outra: o aeroporto, a rodovia, a carona, o transitar, o buscar, o perseguir, o não se acomodar, o dinamismo e a ruptura, interligações do rizoma que revelam o desejo do deslocamento.

Em Onze encontramos não apenas a representação de um mundo em que alguns personagens-ramos estão conectados, em que todas as ações-ramificações realizam impacto sobre a vida de personagens-ramos, mas narrativas que apresentam temporalidades simultâneas e situações que formam sistemas rizomáticos a-centrados, com diversas faces da realidade e velocidades de mundos que coexiste simultaneamente. Assim, a evolução do linear e do genealógico é rompida e em seu lugar ganha espaço a lógica do acaso, do interconectado, da trama neural e da multiplicidade de vozes.

Em contraposição a solidez do livro-árvore que se ramifica nas extremidades, nesse livro-rizoma as ramificações brotam de qualquer ponto, ao acaso, como uma trama que comporta ao mesmo tempo saídas e entradas, entrecruzamentos diversos entre as fibras nervosas que aumentam cada vez mais suas conexões, interseções, sem uma linearidade temporal entre partes e capítulos, revelando assim a potência de conexão e multiplicidade do livro-rizomático de Bernardo Carvalho. Outro princípio que encontramos em Onze é o da heterogeneidade, pois este rizoma não se reduz somente à linguagem, mas é permeado por elementos da ordem do cultural, do político, do social, do subjetivo e do econômico, pois acreditamos que Onze, por representar diversas realidades simultâneas e distintas, esvaziadas de qualquer sentido épico e personagens de feitios cotidianos, em seu dia-a-dia pobre, sujo e contaminado pelo vírus e pela solidão, consegue representar seres de naturezas heterogêneas e, consequentemente, discursos de todas as ordens, agenciando e realizando as conexões entre esses.

\section{O livro-rizoma: raízes de uma obra em movimento}

Dialogando com este conceito vivo e desejante que é o rizoma, Umberto Eco em A poética da obra aberta (1991) traça um perfil da arte hodierna e propõe a noção de obra em movimento para pensarmos as produções estéticas contemporâneas. O filósofo e crítico consegue estabelecer a dialética do movimento (des)construtor interno-externo das produções estéticas, ressaltando que o modo como a arte se estrutura está em sintonia com o modo pelo qual a ciência/cultura vê/lê a realidade. Para o autor, a obra em movimento responde às "tendências da ciência contemporânea", que sustentada na noção de possibilidade e descontinuidades, e abandonando a ordem estática e unidirecional, prioriza a 
complexa interação entre diferentes forças. Nesse sentido, Umberto Eco reitera o laço existente entre o artefato artístico e o mundo, refletindo sobre a impossibilidade de sustentar um discurso unívoco em um mundo cada vez mais heterogêneo, na medida em que as representações dessa condição hodierna clama por novas ferramentas de destruição, transformação, e (re)constituição.

Segundo o autor, são obras em movimento estruturas dinâmicas, móveis, livro-objeto que aguardam combinações distintas, fusões constantes e renovações contínuas, recusando uma forma definitiva e um sentido fixo. Esta definição e categorização de obra é consonante ao conceito deleuzeguattariano de "(livro)rizoma", "(livro)mapa", "livro-máquina-de-guerra", livro desejante que valoriza as literaturas, a multiplicidade sem hierarquias. A obra em movimento, ou o livro rizoma, é aquele que se constrói e reconstrói constantemente, sem gênero, sem espaço-tempo definido, que não tenta estabilizar o que é instável e que busca conexões e estabelece os diálogos interno-externo, com entradas e saídas múltiplas, como um mapa que é

(...) aberto, é conectável em todas as suas dimensões, desmontável, reversível, suscetível de receber modificações constantemente. Ele pode ser rasgado, revertido, adaptar-se a montagens de qualquer natureza, ser preparado por um indivíduo, um grupo, uma formação social. Pode-se desenhá-lo numa parede, concebê-lo como obra de arte, construí-lo como uma ação política ou como uma meditação. Uma das características mais importantes do rizoma talvez seja a de ter sempre múltiplas entradas (DELEUZE e GUATTARI, 1995, p.8)

Tal poética, que se configura como uma poética da sugestão, revela uma nova sensibilidade estética coletiva, o que faz com que os produtores de arte caminhem em direção a uma expansão e dilatação dos veios estéticos da obra, vista não mais como algo estático e fechado, mas sim como um campo de possibilidades, contingências, rupturas e organizações. O teórico, ao recorrer a noções da Física- campo de possibilidades, descontinuidades, indeterminado- a lógica transversal que hoje também busca explicar e conceituar o real segundo princípios nada restritivos, expõe que o que ocorre entre as produções artísticas e as conceituais são correspondências entre analogias de estruturas, ou seja, há uma sugestiva analogia entre o real-referencial e o engendrado artisticamente, noção esta encontrada na construção da narrativa de Bernardo Carvalho, que parece dialogar com noções contemporâneas do pensamento e discurso científico. De acordo com Umberto Eco, tanto um quanto o outro real revelam o ambíguo e o indeterminado, e não mais a forma definida e acabada, não mais o fio que guia Ariadne indicando o caminho certo, o único caminho certo, mas mundos que estabelecem uma relação dialética com o intérprete/leitor, rompendo com as hierarquias entre os diferentes elementos do sistema literário. Em relação a analogia entre real e obra literária, segundo Umberto Eco “(...) não será ousado reencontrar na poética da obra "aberta" (e mais ainda, da obra em movimento) (...) as ressonâncias vagas ou definidas de algumas tendências da ciência contemporânea" (1971, p.56)

Tal conceituação revela a densidade da construção estética que encontramos em Onze, na medida em que esse romance apresenta não somente o intenso diálogo com uma nova conceituação de real, que considera o incerto, o descontínuo, a profusão, mas também exige deslocamentos constantes por parte do seu leitor, que deve buscar as conexões realizadas entre as distintas 
ramificações de um livro-rizoma sem proposição fundamentada, sem uma linearidade contínua, pois cada narrativa é um território instável, sujeito a interferência de um ramo externo, pronto para ser invadido, transpassado e entrecruzado por uma nova ramificação.

\section{Considerações finais}

Onze, ao revelar um enredar-se e ramificar-se constante, nos apresenta uma imago mundi da vida, da pulsação, do destino, do encontro com o outro, do devir, do (re)fazer-se constante e do transformar-se incessantemente no/do mundo. A relação entre os vários personagens que, ao representarem as inúmeras ramificações de um rizoma, se entrelaçam e se engalfinham, formam um conjunto complexo no qual os elementos remetem não somente uns aos outros, mas para fora do próprio conjunto. Analogicamente guarnecido no baluarte conceitual do revolucionário conceito de rizoma, de Gilles Deleuze e Félix Guattari, o qual nos forneceu suporte para acompanhar "os movimentos de desterritorialização e desestratificação" (1995, p.15) dos personagens-ramos e os temas-bulbos que irromperam e alastraram-se desenhando o inacabado, o desejo da busca, a procura e o (des)encontro, Onze foi visualizado como um verdadeiro terreno de "direções movediças", sem começo nem fim, mas um meio pelo qual seus ramos cresceram e transbordaram.

Nesta obra, na qual aflora a cada nova linha o princípio de conexão, devido a relação entre personagens, saberes e vidas, não encontramos seleção e trânsitos regidos pela hierarquia, mas sim o múltiplo, pois ainda que o título da obra insista em uma unidade (Onze: uma história), o que visualizamos é uma conexão apenas fugidia, uma unidade fugaz, sem cerne e raiz principal a qual ancorar raízes, mas apenas um caule radiciforme composto por linhas-personagens-temas de confluências fibrosas. Não conseguimos reduzir e centrar o rizoma, assim como não conseguimos fazê-lo com as ramificações de Onze. Não há raízes principais, apenas bulbos que a cada (re)leitura podem ser (re)descobertos, conectando assim (mais) um ponto a outro, configurando uma obra sempre em devir, uma imago mundi feito mapa de renovado traço, a cada instante-instável, a ser descoberto e explorado na qual podemos nos debruçar a partir de qualquer ponto, pois, de entrada múltipla, revela a cada nova linha, a cada novo traço seu princípio cartográfico, fazendo assim não rizoma do mundo, mas rizoma com o mundo. 


\title{
Onze: the rhizomatic narrative of the Bernardo Carvalho
}

\begin{abstract}
This article aims to analyze the novel Onze (2011) the author Bernardo Carvalho from of the rhizome theory of theoretical Gilles Deleuze and Felix Guattari, this last thought from a social reading. Interpreting this novel and understanding their discursive structure, we propose an analogy between this literary work and external social structures identified by deleuze-guatariana theory in order to understand "Eleven" as a narrative-rhizome.
\end{abstract}

PALAVRAS-CHAVE: Rhizome. Contemporary narrative. Onze. 


\section{NOTAS}

1 Ainda que os autores afirmem que "O livro como imagem do mundo é de toda maneira uma ideia insípida", (DELEUZE E GUATTARI 1995, p.04), acreditamos que esta imago mundi considerada por Deleuze e Guattari representa o mero reflexo do mundo pela arte literária através de uma lógica binária simplista. No entanto, consideramos imago mundi o resultado do trabalho de recriação do real, e não uma reprodução ou cópia de determinada realidade. O livro como máquina-livro, e não como máquina-decalque.

2 Grifo em negrito nosso.

\section{REFERÊNCIAS}

BRAVO, Victor; Terrores del fin de milenio. Mérida, Ediciones El Libro de Arena Talleres Gráficos Universitarios, 1999.

CANDIDO, Antônio; Literatura e sociedade. Rio de Janeiro: Ouro sobre azul, 2006.

CARVALHO, Bernardo; Onze: uma história. São Paulo: Companhia das Letras, 1995.

DELEUZE, Giles. \& GUATTARI, Félix; Introdução: Rizoma. Texto extraído de Mil Platôs (Capitalismo e Esquizofrenia) Vol. 1. Editora 34, 1995.

ECO, Umberto; Obra aberta: forma e indeterminação nas poéticas contemporâneas. 2. ed. São Paulo: Perspectiva, 1971.

MORIN, Edgar; Introducción al Pensamiento Complejo. España: Gedisa Editorial. 1990. 
Recebido: 21 mar. 2016

Aprovado: 30 set. 2016.

DOI: $10.3895 /$ rl.v18n22.3833

Como citar: SOUZA, L. B.; VIANNA, V.C.L. Onze: a rizomática narrativa de Bernardo Carvalho. R. Letras, Curitiba, v. 18, n. 22, p. 20-38, jan./jul. 2016. Disponível em: <https://periodicos.utfpr.edu.br/rl>. Acesso em: XXX

Direito autoral: Este artigo está licenciado sob os termos da Licença Creative Commons-Atribuição 4.0 Internacional.

(c) (1) 